\begin{tabular}{|} 
Ambiente \& Água - An Interdisciplinary Journal of Applied Science \\
ISSN 1980-993X - doi:10.4136/1980-993X \\
www.ambi-agua.net \\
E-mail: ambi.agua@gmail.com
\end{tabular}

\title{
Performance of slow sand filters in the after-treatment of effluent from Pernambuco state textile center
}

\author{
ARTICLES doi:10.4136/ambi-agua.2586
}

Received: 23 May 2020; Accepted: 15 Sep. 2020

\begin{abstract}
Alanna Maria do Nascimento Bezerra1 ${ }^{1}$; Marcos Henrique Gomes Ribeiro ${ }^{2}{ }^{D}$; Artur Paiva Coutinho ${ }^{1}$; Ana Emília Carvalho de Gusmão da Cunha Rabelo ${ }^{3}$; Elizabeth Amaral Pastich Gonçalves ${ }^{1 *}$ (iD
\end{abstract}

\footnotetext{
${ }^{1}$ Centro Acadêmico do Agreste. Núcleo de Tecnologia. Universidade Federal de Pernambuco (UFPE), Avenida Marielle Franco, s/n, Km 59, CEP: 55014-900, Caruaru, PE, Brazil.

E-mail: alannamnb@gmail.com, artur.coutinho87@gmail.com

${ }^{2}$ Centro de Tecnologia e Geociências. Departamento de Engenharia Civil e Ambiental. Universidade Federal de Pernambuco (UFPE), Avenida da Arquitetura, s/n, CEP: 50740-550, Recife, PE, Brazil.

E-mail: mhgribeiro@gmail.com

${ }^{3}$ Centro de Tecnologia e Geociências. Departamento de Energia Nuclear. Universidade Federal de Pernambuco

(UFPE), Avenida Luiz Freire, n 1000, CEP: 50740-545, Recife, PE, Brazil. E-mail: anaerabelo@gmail.com

*Corresponding author. E-mail: bethpastich@yahoo.com.br
}

\begin{abstract}
Jean laundering generates significant effluent flows with a high organic load, color, and other pollutants, making it difficult to adjust effluent releases within legal limits. Slow Sand Filters (SSF) with downflow were tested for seven days (bench scale), to propose an aftertreatment of effluents from an Effluent Treatment Plant of a jean laundry. The research evaluated the removal of the following parameters: color, turbidity, chemical and biochemical oxygen demand, conductivity, ammonia, total phosphorus and salinity of the textile effluent. The experimental apparatus had four SSF: the first filter was fed with distilled water, while the other three filters (triplicates) were fed with effluent. The filters had, on average, the following removal efficiencies: $91 \%$ for ammonia, $61.24 \%$ color, $89.43 \%$ turbidity, and $83.54 \%$ for phosphorus. Regarding the removal of organic matter, $98.11 \%$ for BOD and $81.17 \%$ for COD, demonstrating that SSFs were efficient in removing particulate, dissolved materials and organic matter.
\end{abstract}

Keywords: BOD, color, dissolved oxygen, salinity, soil column.

\section{Desempenho de filtros lentos de areia no pós-tratamento de efluente do polo têxtil do estado de Pernambuco}

\section{RESUMO}

As lavanderias de Jeans geram grandes vazões de efluentes com elevada carga orgânica, cor e outros poluentes, o que dificulta sua adequação para lançamentos dentro dos limites legais. Filtros lentos de areia (FLA) com fluxo descendente foram testados durante 7 dias, em escala de bancada, a fim de propor um pós-tratamento de efluentes de uma Estação de Tratamento de Efluentes de lavanderia de jeans. Nesta pesquisa, foi avaliada a remoção dos seguintes parâmetros: cor, turbidez, demanda química e bioquímica de oxigênio, condutividade, amônia, 
fósforo total e salinidade. O experimento contou com quatro FLA: o primeiro alimentado com água destilada e os outros três alimentados com o efluente têxtil (triplicatas). Os FLA removeram $91 \%$ de amônia, $61,24 \%$ de cor, $89,43 \%$ de turbidez e $83,54 \%$ de fósforo. Quanto à remoção de matéria orgânica, em média houve remoção de $98,11 \%$ para $\mathrm{DBO}$ e $81,17 \%$ para DQO, demonstrando que os FLA foram eficientes na remoção de materiais particulados e dissolvidos.

Palavras-chave: coluna de solo, cor, DBO, oxigênio dissolvido, salinidade.

\section{INTRODUCTION}

The Brazilian semiarid is characterized as a region of low water availability (Rocha and Soares, 2015). Despite its negative water balance, the area has outstanding Local Productive Arrangements (LPA). The Pernambuco Agreste clothing center, known as "Mode LPA", is composed of Caruaru, Santa Cruz do Capibaribe, and Toritama, embracing the second largest textile center in Brazil, which is an essential sector for the region's development. However, according to Abreu et al. (2008), due to the water scarcity in the area and the lack of adequate effluent treatment systems, the implementation of the textile industry imposes a severe environmental and health risk for the surrounding community, mainly due to the mutagenic and carcinogenic nature of dyes and their intermediate byproducts (sludge and textile effluents).

Throughout the methods for textile processing, different constituents are generated, such as acids, bleaching chemicals, enzymes, starch, dyes, resins, solvents, waxes, oils, among others. (Verma et al., 2012). These constituents produce a final effluent with high COD, BOD, total dissolved solids, color, and heavy metals (Chandanshive et al., 2017). This can result in chronic nutrient accumulation leading to artificial eutrophication, promoting change in the water color and exposing aquatic life to toxic substances (Esteves and Meirelles-Pereira, 2011).

There are many alternatives for treating textile effluents, which are combined to achieve a satisfactory level of waste removal. There is the use of anaerobic-reactor type UASB conjunction with process Fenton (Santos et al., 2017), chemical coagulation followed by lamella settler for sedimentation and disinfection (Abdel-Fatah et al., 2015), submerged anaerobic membrane bioreactors (Baêta et al., 2016), use of live microalgae in suspension (Jimeno et al., 2017) and a solid state fermentation system (Chicatto et al., 2018) for waste water discoloration.

Soils have good retention capacity for textile contaminants, especially in the case of dyes (Alexandre et al., 2020; Alves et al., 2020), proving that simple techniques also produce satisfactory results. Therefore, slow sand filtration appears as a simple alternative for treating textile effluents. Slow sand filtration is characterized by a low filtration rate, resulting in a high water retention time, which implies the development of a microbial community (Dias, 2011). The biological community developed around the grains of the sand bed assists in the appropriate process of removing suspended organic and inorganic matter and pathogenic organisms (Coelho and Di Bernardo, 2012). According to Tonetti et al. (2012), the process of this type of technology is based on applying the effluent on the surface of the sand filter intermittently through a distribution pipe. When the infiltration of the liquid persists, its purification by physical, chemical and biological processes comes about (Ausland et al., 2002).

Investigations regarding the use of slow filters for the treatment of textile effluent are essential to evaluate pollutants' retention potential (Egea-Corbacho et al., 2019), and thereby reducing the environmental risks, treatment costs, and areas used for treatment plants. Due to their simplicity and lower operating costs, slow filters are currently an attractive solution, especially in rural areas and small communities in developing countries (Bendida et al., 2013). Among the advantages of slow filters over fast filters, a highlight is not requiring water 
coagulation and frequent washing of the filtration units which results in high production of waste. The sand taken from the top of the filter layer can be washed or disposed of as dirty sand (Grace et al., 2016).

In this context, this research evaluates the performance of slow sand filters in the treatment of textile effluents from Pernambuco's Textile Center. It also assesses its efficiency in the suitability of the textile effluent for release into the water body and for hydro-agricultural reuse.

\section{MATERIALS AND METHODS}

\subsection{Study area}

The study was conducted in the city of Caruaru, in Pernambuco State, Brazil. The municipality belongs to the Mesoregion of Pernambuco's Agreste and is in the Ipojuca Valley Microregion. Caruaru has a dry climate of local steppe, with little rainfall throughout the year, corresponding to about $551 \mathrm{~mm}$ per year (APAC, 2019).

According to the latest IBGE census (IBGE, 2010), Caruaru has a population of 314,912 inhabitants, which ranks the region as the fourth most populous city in Pernambuco and the most populous municipality in the interior of the state. It is currently the Agretes' capital, standing out as the most significant economic, medical, academic, cultural, and tourist center of the region. Among these industrial activities, clothing and textiles are those that are most relevant, being responsible for the development and expansion of the municipality's economy.

\subsection{Textile effluent collection site}

The treated effluent used in this study was directly collected from a medium-sized textile laundry located in the city of Caruaru. This laundry has a production system based on degreasing, dyeing, washing, spinning and drying, as do most laundries in the region. The laundry effluent treatment plant in question is composed of a physical-chemical treatment, comprising coagulation, flocculation and decantation steps. The collected textile effluent was transported in a polypropylene container, properly sealed with a lid, previously sterilized in the laboratory by autoclaving. The sample was transported to the Environmental Engineering Laboratory (Laboratório de Engenharia Ambiental - LEA) and subsequently stored about 20 min after collection in the laundry under refrigeration at $4^{\circ} \mathrm{C}$.

\subsection{Soil sample collection}

The soil sample used in the sand filter experiment was collected at an experimental site belonging to the Agreste Academic Center of the Federal University of Pernambuco, located in the city of Caruaru. At first, the site was cleaned so that undesirable materials such as roots and vegetation could be removed from the soil. To collect the sample, tools such as shovel, hoe, and pick were used, to obtain a portion equivalent to $20 \mathrm{~cm}$ of the soil layer to fill the sand filters.

After collecting the soil sample, a soil characterization test was performed to determine the physical indices of the sample.

For the determination of the soil bulk density, the criteria established in the Manual of Soil Analysis Methods (Claessen, 1997) was adopted. Particle size analysis was performed according to the requirements of NBR 7181 (ABNT, 1984). To determine the soil density, undisturbed samples were collected using the Uhland soil sampler.

From this soil sample, the grain fractions were also determined based on sieve and sedimentation analysis. This test aims to obtain the soil particle-size curve and identifies its granular dimensions.

\subsection{Assembly of slow sand filters}

Slow sand filters (SSF) were assembled on a cylindrical acrylic column (Figure 1). The cylinders have an inner and outer diameter of 6 and $7 \mathrm{~cm}$, respectively, with a height equivalent 
to $30 \mathrm{~cm}$. A transparent material composes the acrylic cylinders to facilitate the monitoring of the flow path of the used effluent sample.
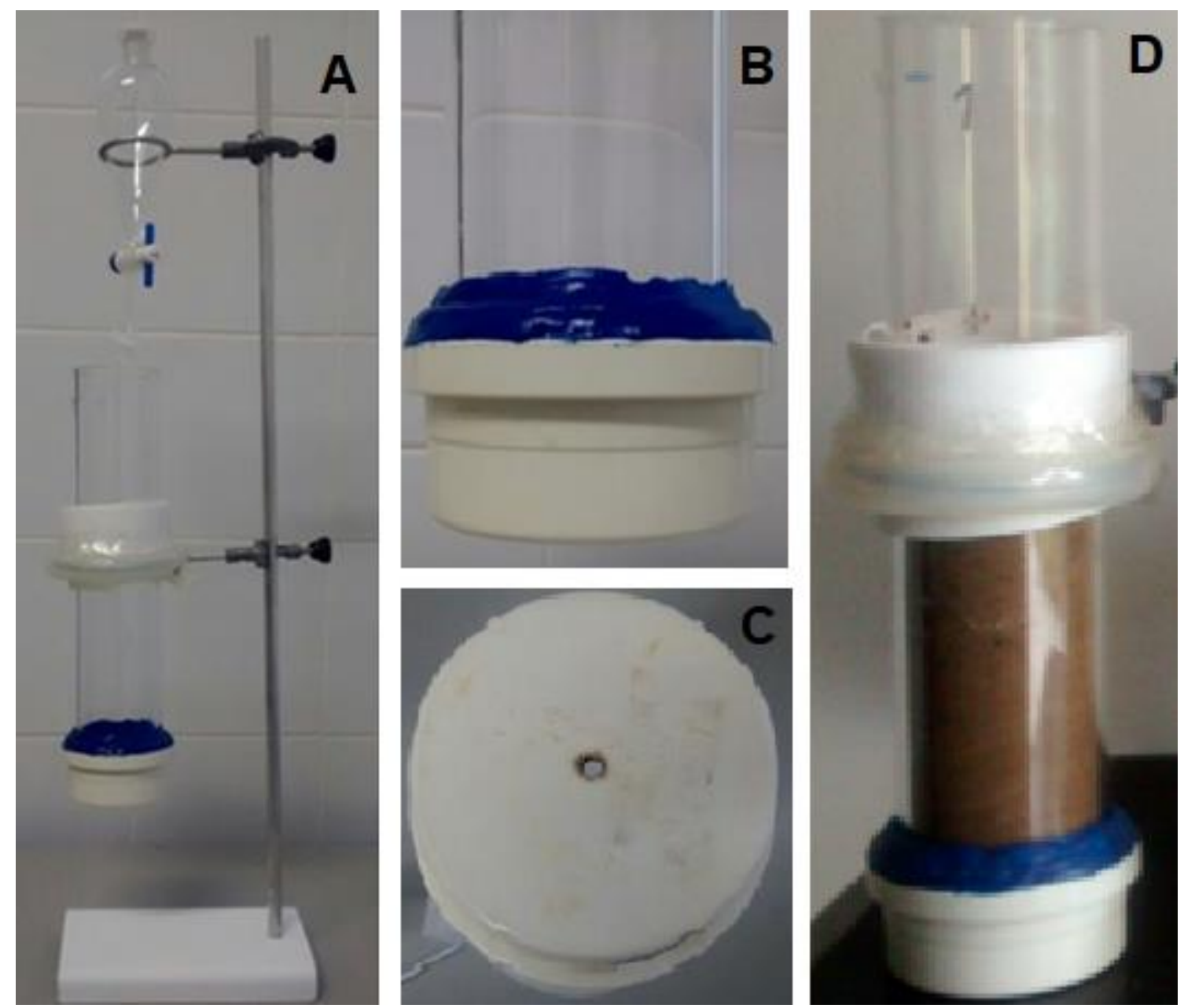

Figure 1. Assembly of a slow sand filter: a) Support model for the column and filter feeder; b) Sealing rubber and PVC cover for column sealing; c) Drilled hole for leachate passage; d) Filter filled with soil.

On the outside of the filters, to ensure better support of the tubes in the metal supports, rubberized material such as Satin Vinyl Foam (S.V. F.) adhered to the hose was used, and the two materials were fixed with hot glue. Thus, the slow sand filters could be supported on the metal rod and suspended (Figure 1a) so that the leachate could be collected at the tube`s bottom.

In the lower part of the filters, a $75 \mathrm{~mm}$ diameter pipe end-cap, generally used for a PVC sewage pipe, was used to seal the ground passage, and each cap was fixed at the bottom of each tube using rubber seal (Figure 1b). Finally, a hole was drilled in the center of each end cap (Figure 1c) to ensure the passage of leached samples through the filters.

A $20 \mathrm{~cm}$ single layer, consisting of the collected sand (Figure 1d) was used to finish the assembly of the sand filters. Therefore, the filters were filled to ensure the same density as in the field. To reach a density of $1.32 \mathrm{~g} \mathrm{~cm}^{-3}, 746.44 \mathrm{~g}$ of soil were required for each sand filter, because the filters needed to maintain a fixed height of $20 \mathrm{~cm}$, and the inner diameter of each tube was $6 \mathrm{~cm}$.

\subsection{Experimental procedure}

Four sand filters named SSF1, SSF2, SSF3, and SSF4 were used for this research. The first slow sand filter (SSF1) was fed with distilled water to serve as control to the experiment. The 
other three filters (SSF2, SSF3, and SSF4) were irrigated with the textile effluent collected in the laundry.

Slow sand filters are characterized by infiltration rates between 2 and $6 \mathrm{~m}^{3} \mathrm{~m}^{-2}$ day . Therefore, for the present study filters with an infiltration rate equal to $4.24 \mathrm{~m}^{3} \mathrm{~m}^{-2}$ day $^{-1}$ were used, which was measured by the time required for all the liquid to be leached through the filter and adjusted with the aid of the flow regulating funnel.

Regarding the leachate volume, it was established that the volume in each sand filter would comprise only $125 \mathrm{~mL}$ per day over seven days, as it is the time limit for the main characteristics of the textile effluent to be fully conserved and used during the leaching. Table 1 presents the parameters evaluated in the textile effluent (crude and leachate), the analysis frequency, and employed method, based on APHA et al. (2012).

Table 1. Parameters evaluated in textile effluent.

\begin{tabular}{ccc}
\hline Parameters & Employed Method & Frequency \\
\hline pH & conductivity & nephelometric \\
Turbidity & spectrophotometric \\
Color & conductivity & Daily, for seven days \\
Conductivity & multiparameter probe \\
Salinity & multiparameter probe \\
Temperature & membrane electrode \\
OD & manometric \\
BOD & colorimetric \\
COD & titrimetric & Once, on the last day of the experiment \\
Ammoniacal Nitrogen & colorimetric & \\
Phosphorus &
\end{tabular}

\section{RESULTS AND DISCUSSION}

Table 2 shows the percentages of sand, silt and clay, and the textural classification. According to these data, the soil is classified as sand with compact angular granulation and has an average apparent porosity of $55.97 \%$. The textural classification is of type Sandy Loam.

Table 2. Particle-size fraction of the soil used for the filters.

\begin{tabular}{lcc}
\hline \multicolumn{2}{l}{ Particle-size fraction } & Proportion (\%) \\
\hline Clay & - & 16.06 \\
\hline Silt & - & 22.88 \\
\hline \multirow{3}{*}{ Sand } & Very fine & 5.90 \\
& Fine & 16.12 \\
& Medium & 13.37 \\
& Coarse & 12.02 \\
& Very coarse & 9.19 \\
\hline
\end{tabular}

Figure 2 shows the particle-size curve observed in the sand (soil) sample. In Brazil, NBR 
13969 (ABNT, 1997) regulates sand filter size. According to this standard, the effective average diameter (D10), the non-uniformity coefficient (CNU) and the depth of the sand layer should be considered in the project. These criteria are also evaluated by the USEPA (1999) standard.

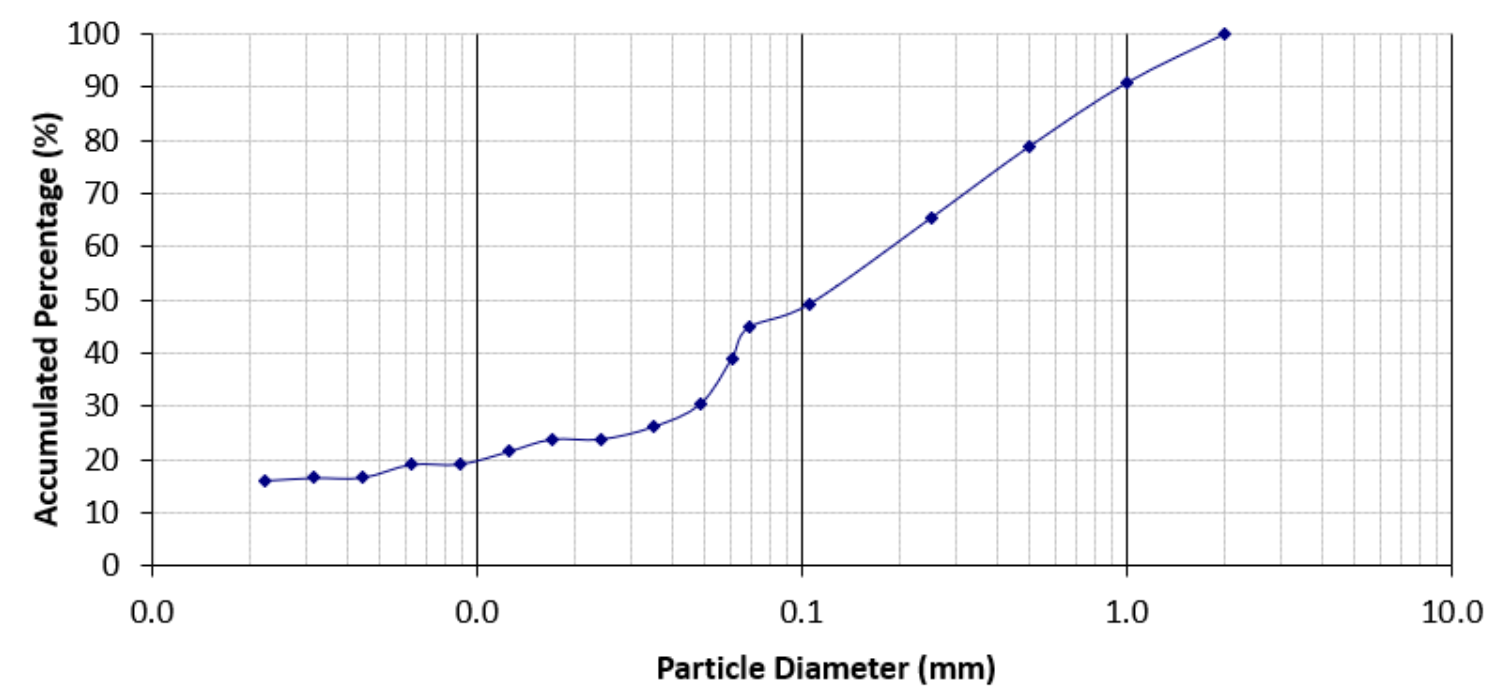

Figure 2. Particle-size distribution curve of the used sand.

The effective mean diameter (D10) affects the infiltration rate of the affluent in the riverbed and the penetration depth of the insoluble solid matter. The non-uniformity coefficient represents the inequality in particle size. The higher this parameter, the better graded is the sand. The characteristics of the filter media are summarized in Table 3 and compared to the previously mentioned current standards.

Table 3. Summary of filter characteristics and comparison with the cited standards.

\begin{tabular}{lccc}
\hline \multirow{2}{*}{ Parameters } & \multicolumn{3}{c}{ Consulted Normatives } \\
\cline { 2 - 4 } & SSF & NBR 13969:1997 & USEPA (1999) \\
\hline Sand Depth (m) & 0.20 & 0.70 & 0.45 to 0.91 \\
Soil type & Sandy loam & n.s & n.s \\
Effective average diameter (D10) $(\mathrm{mm})$ & 1.00 & 0.25 to 1.20 & 0.25 to 0.75 \\
Non-uniformity coefficient (CNU) & 0.062 & Lower than 4 & Lower than 4 \\
\hline
\end{tabular}

Note: n.s.= non specified.

The effective average diameter (D10) is equal to the diameter of the sieve that allows $10 \%$ of the soil to pass through. From Figure 2, it can be inferred that the passing percentage of $10 \%$ equals the cumulative percentage of $90 \%$, assigning a value equal to $1.00 \mathrm{~mm}$ for D10. The non-uniformity coefficient (NUC) is equivalent to the diameter of the sieves that allow $60 \%$ of the soil divided by D10 to pass. Similarly, $60 \%$ of the passing soil equals $40 \%$ of accumulated soil, this value being 0.062, as observed in Figure 2. Thus, the NUC is 0.062 . Therefore, these two parameters make the chosen soil suitable for use as a slow sand filter material.

Figure 3a shows the dynamics of the textile effluent's $\mathrm{pH}$ before and immediately after filtration and Figure $3 \mathrm{~b}$ shows the study of dissolved oxygen slow sand filters. 


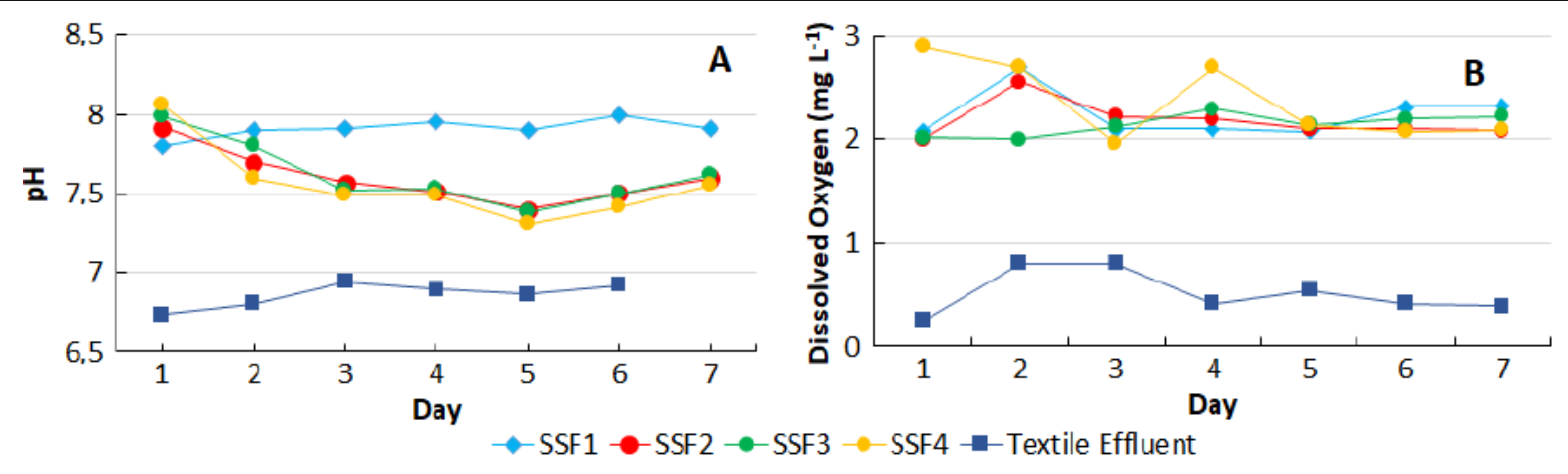

Figure 3. Graphs for daily analysis of $\mathrm{pH}$ and dissolved oxygen of textile effluents before and after filtration.

When the purpose of the effluent's treatment is to use it as agricultural reuse water, the $\mathrm{pH}$ becomes relevant once the soil texture and structure are known. The $\mathrm{pH}$ of water, along with the soil and plant species, determine nutrient uptake by the capillary root (Souza et al., 2010). The water used for irrigation must remain in the $\mathrm{pH}$ value range between 6.5 and 8.4. If wastewater presents values outside this range, it may cause nutritional imbalance to the plant (Sousa et al., 2005). From the results expressed in Figure 3a, it is observed that the $\mathrm{pH}$ values for the leachate of SSF2, SSF3, and SSF4 (irrigated with textile effluent) presented results within the allowed $\mathrm{pH}$ range. According to Armindo et al. (2015), changes in $\mathrm{pH}$ may cause the solidification of some elements that were previously dissolved. The already established $\mathrm{pH}$ value range must also be met to avoid problems with pipes and equipment used for irrigation.

Conversely, the $\mathrm{pH}$ of the collected samples, after going through SSF2, SSF3, and SSF4, presented an average value of 7.6. This result is close to the average value for SSF1, a filter filled with distilled water. Brazilian Resolution No 430 (Conama, 2011) recommends $\mathrm{pH}$ values for effluent discharge into receiving bodies between 5 and 9; in other words, the filtered samples reached the values allowed by the standard.

The dissolved oxygen (DO) concentration shown in Figure $3 \mathrm{~b}$ is directly linked to the presence of organic matter. Once in aerobic organic matter stabilization processes, the DO is consumed by bacteria, as well as by other chemical and biological processes that consume DO from the environment. In general, the higher the DO concentration in water sources, the better the water quality from the perspective of this parameter. According to Figure $3 \mathrm{~b}$, it is noticed that the textile effluent presented much lower dissolved oxygen concentrations than the samples that passed through the filtration. The low DO result for the effluent can be explained by the high level of COD and BOD.

The high concentrations of DO compared to the values expressed before passing through the filters demonstrate the high aeration capacity of slow, intermittent sand filters. Aeration can be explained by the time the filters rest between applications, as applications were performed every 24 hours. In this way, the air is allowed into the sand pores, positively meeting the metabolism of aerobic bacteria and allowing dilution of oxygen in the liquid mass.

The average DO value for filters that received the textile effluent was $2.23 \mathrm{mg} \mathrm{L}^{-1}$. Tonetti et al. (2012) showed that waters with these dissolved oxygen concentrations can be used for irrigation of vegetables, fruit and park plants, as well as aquaculture.

Figure 4a shows the turbidity before and after filtration and Figure $4 \mathrm{~b}$ shows the study of color. Turbidity, shown in Figure 4a, is caused by the presence of suspended particles in water. It is an essential property in localized irrigation because sedimented water can cause emitter clogging, altering the flow rate. This physical characteristic can be reduced through the filtration process. The results for the slow sand filters are much lower than the values for the textile effluent. 


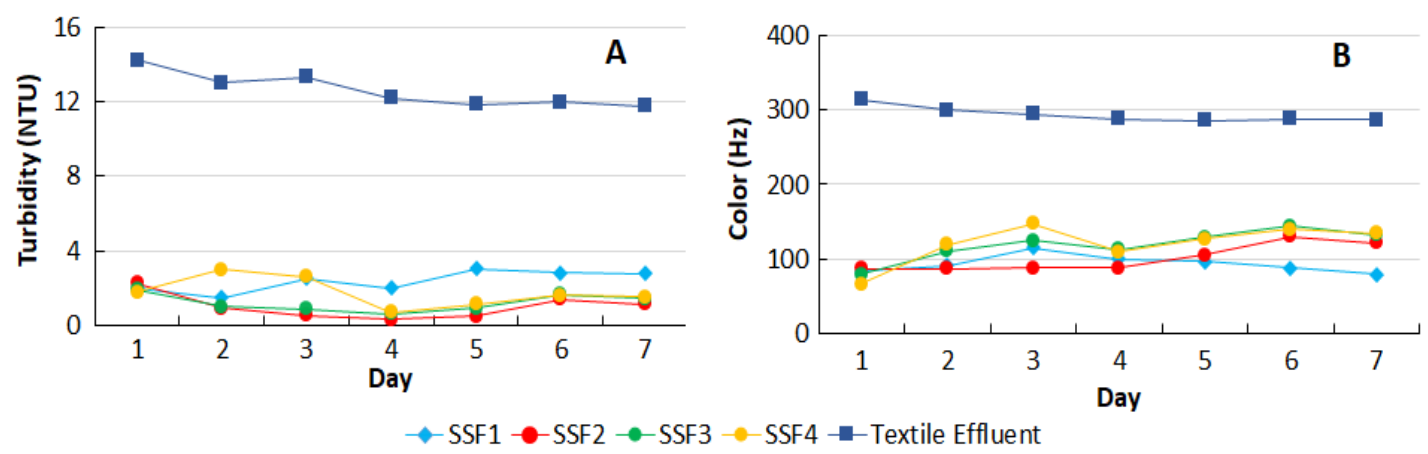

Figure 4. Graphs for daily analysis of turbidity and color of textile effluents before and after filtration.

The textile effluent, before application on the filters, presented an average turbidity of 12.61 NTU. The average turbidity for SSF2, SSF3, and SSF4 (leachate) filters was 1.3 NTU, which is considered an acceptable value for localized irrigation systems regarding clogging problems. Paterniani et al. (2008) conducted a study with slow filters to remove suspended solid particles in water samples. The study obtained turbidity values up to $16.9 \mathrm{NTU}$ and no clogging problems were detected in the drip irrigation system.

The color of a sample, shown in Figure 4b, indicates the presence of dissolved organic or inorganic matter and refers to the presence of suspended material, being a parameter that can be quickly and easily determined (Heller et al., 2007). Figure 4b shows the study of apparent color for slow sand filters. It was observed that the results for the slow sand filters irrigated with textile effluent (SSF2, SSF3, and SSF4) presented values close to the values of slow sand filters irrigated with distilled water (SSF1). That evidence shows that none of the filters had high leaching of the soil in the pipes.

It can be inferred that the color values for SSF2, SSF3, and SSF4 (leachate) were lower than the values presented in the raw textile effluent, with results close to those from SSF1. The efficiency of apparent color removal on the filters was, on average, 61.24\%. According to findings presented by Paterniani et al. (2011), the slow sand filter used in this study as a filter medium for treated domestic effluent, with a soil layer of $75 \mathrm{~cm}$, presented an efficiency of $26 \%$. Therefore, it could be used in fertigation practices.

Figure 5a shows the electric conductivity before and after filtration and Figure $5 \mathrm{~b}$ shows the study of salinity. Through graphical analysis (Figure 5a), it was observed that the electrical conductivity in Filter 1 (SSF1), which was fed with distilled water, remained lower than the effluent, which was already expected, and constant over the days. The conductivity of the used water increased to feed the filter with the leachate; this was due to the ions that were carried from the soil along with the sample because the distilled water used to irrigate the filter had a value below $3 \mu \mathrm{S} \mathrm{cm}^{-1}$.
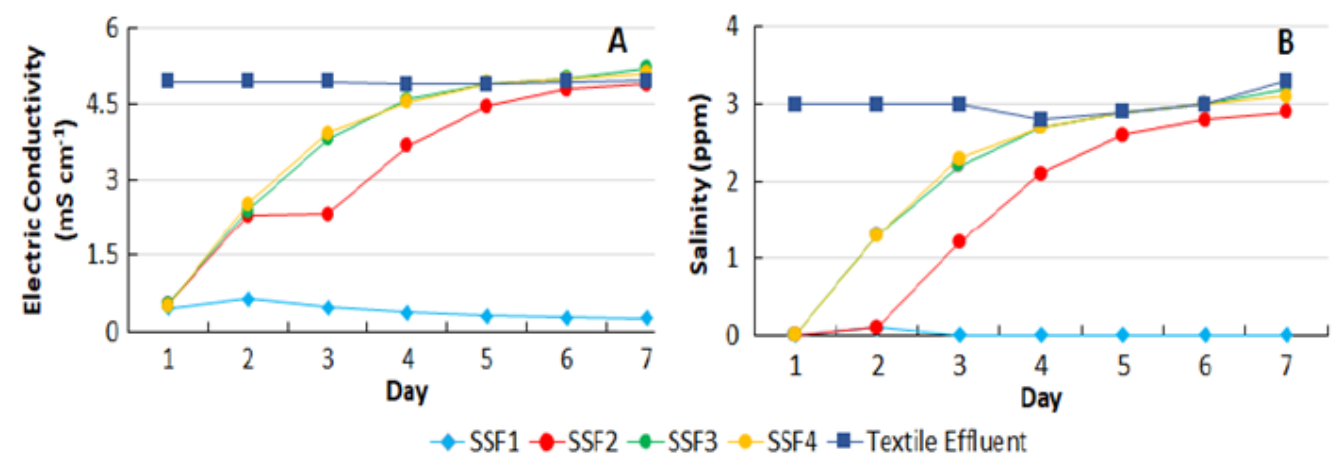

Figure 5. Graphs for daily analysis of electric conductivity and salinity of textile effluents before and after filtration. 
For SSF2, SSF3, and SSF4, it was observed that the electrical conductivity tended to reach the values of the used textile effluent, elucidating the fact that the soil reached possible saturation in relation to the ions, leaching the ions present in the effluent sample and reaching equilibrium. In general, the electrical conductivity of the SSF2, SSF3, and SSF4 filters presented an average value of $3610 \mu \mathrm{S} \mathrm{cm}^{-1}$. According to the data presented by Jeong et al. (2016), if the electrical conductivity of irrigation water is below $700 \mu \mathrm{S} \mathrm{cm}^{-1}$, crop growth will not be affected. However, if the electrical conductivity value is above $3000 \mu \mathrm{S} \mathrm{cm}^{-1}$, it can cause severe damage, characterizing the irrigation water as improper.

According to the primary and practical concepts established for water quality for irrigation purposes (Cordeiro, 2001), the average electrical conductivity value obtained in samples after passage through slow filters, characterized it as Class 4, i.e., very high salinity. However, if water is used for disposal in the soil, they must be permeable and have adequate drainage (Mancuso and Santos, 2003). Irrigation should be done in excess, providing considerable dissolution and the selected vegetation should be salt tolerant.

Salinity (Figure 5b) is a very limiting factor for irrigation as plant development and growth can be impaired. It was possible to observe that SSF1 showed practically no salinity record, demonstrating that the solvent (distilled water) and the soil used in the filters did not show salinity levels. The filters irrigated with the effluent presented behavior similar to the results expressed by the electrical conductivity. The salinity of SSF2, SSF3, and SSF4 increased during the experiment, converging with the effluent used.

The salinity values for the leachate from the irrigated filters with textile effluent do not meet the established standards for irrigation (Cordeiro, 2001). These results can be compared to the electrical conductivity values, which may leave the irrigated soil saline and infertile, impairing the development of plants. The more salts present in water, the higher the ability of water to conduct electric current. The presence of water-soluble salts can lead the soil to salinization conditions, harming plant growth. Thus, water with high concentrations of electrical conductivity should be avoided.

Another practice to reduce salinity problems is to apply an additional amount of water to leach out salts from irrigation. Nevertheless, the irrigation frequency and the application depth can be adjusted.

However, according to Armindo et al. (2015), it is possible to minimize the risk of salinity with sound soil and crop management. If the soil remains saline due to irrigation, crops that can grow satisfactorily under such conditions should be selected. Another practice to reduce salinity problems is to apply an additional amount of water to leach out salts from irrigation. Even so, the irrigation frequency and the application depth can be adjusted.

Table 4 shows the average BOD, COD, ammoniacal N, phosphorus, turbidity and color results for effluent samples before and after filtration. From the analysis of Table 4, it is noted that the textile effluent presented a BOD concentration of $440 \mathrm{mg} \mathrm{L}^{-1}$. This value when compared to the results of SSF2, SSF3, and SSF4 shows that the type of filter used in this experiment was able to significantly reduce BOD concentrations, with approximately $98 \%$ efficiency, adjusting the final effluent for the release. The removal of organic matter may have occurred by organic matter mineralization, degradation by aerobic microorganisms, and its accumulation in the soil. Resolution No. 430 (Conama, 2011) evidences that the permitted removal for release in watercourses should be $60 \%$, which is a sound result. SSF1, when irrigated with distilled water. The efficiency of turbidity removal averaged $89 \%$, which means a good performance.

Ammonia nitrogen and total phosphorus data are also presented in Table 4. The Table showed a high concentration of ammonia nitrogen and phosphorus for the textile effluent, which was already expected due to the chemicals used in industrial laundry processes. Table 4 also demonstrated that there was nutrient incorporation into the soil due to the low concentration of 
these parameters directly after the textile effluent passes through the slow sand filters. Ammonia nitrogen and phosphorus values presented in SSF1 are due to their concentrations in the soil, which were leached during the filtration process.

Table 4. Mean results of parameters for effluent samples before and after filtration.

\begin{tabular}{|c|c|c|c|c|c|c|}
\hline \multirow{2}{*}{ Parameter } & \multirow{2}{*}{ Values before the filters } & \multicolumn{4}{|c|}{ Values after the filters (leachate) } & \multirow{2}{*}{ Removal efficiency (\%) } \\
\hline & & SSF1 & SSF2 & SSF3 & SSF4 & \\
\hline $\mathrm{BOD}\left(\mathrm{mg} \mathrm{L}^{-1}\right)$ & 440 & 0 & 10 & 10 & 5 & $98.11 \pm 0.66$ \\
\hline $\mathrm{COD}\left(\mathrm{mg} \mathrm{L}^{-1}\right)$ & 756.01 & 78.39 & 124.33 & 165.45 & 136.34 & $81.21 \pm 2.80$ \\
\hline Ammoniacal $\mathrm{N}\left(\mathrm{mg} \mathrm{L}^{-1}\right)$ & 29.12 & 2.24 & 1.12 & 3.92 & 2.80 & $91.03 \pm 4.84$ \\
\hline Phosphorus (mg L $\mathrm{m}^{-1}$ ) & 3.69 & 1.74 & 0.61 & 0.80 & 0.42 & $83.54 \pm 5.12$ \\
\hline Turbidity (NTU) & 14.24 & 2.38 & 1.02 & 1.21 & 1.76 & $90.33 \pm 1.34$ \\
\hline Color $(\mathrm{Hz})$ & 314 & 80 & 122 & 133 & 135 & $58.60 \pm 2.23$ \\
\hline
\end{tabular}

According to Sousa et al. (2005), ammonia nitrogen values above $30 \mathrm{mg} \mathrm{L}^{-1}$ are not recommended for irrigation. For sensitive cultures, ammoniacal nitrogen concentrations above $5 \mathrm{mg} \mathrm{L}^{-1}$ result in negative effects. The filters were able to adjust the textile effluent for irrigation, reducing the initial concentration of $29.12 \mathrm{mg} \mathrm{L}^{-1}$ to values below $2 \mathrm{mg} \mathrm{L}^{-1}$.

Resolution $\mathrm{N}^{\mathrm{o}} 430$ (Conama, 2011) indicates that the maximum value for ammonia nitrogen for effluents discharged into receiving bodies should be a maximum of $20 \mathrm{mg} \mathrm{L}^{-1}$. The ammonia nitrogen values indicate that the filters were able to adapt the treated effluent for release into water bodies.

Figure 6 shows the final balance of the COD, ammonia nitrogen, and total phosphorus parameters. The COD (Figure 6a) of SSF2, SSF3 and SSF4, compared to that of the textile effluent used to feed the filters, proves that the incorporation of organic matter in the soil was approximately $81.17 \%$. According to Paterniani et al. (2011), these values are considered acceptable if the reuse purpose is fertigation of cooked, consumed plants, fertigation of inedible plants and reuse for environmental improvement.

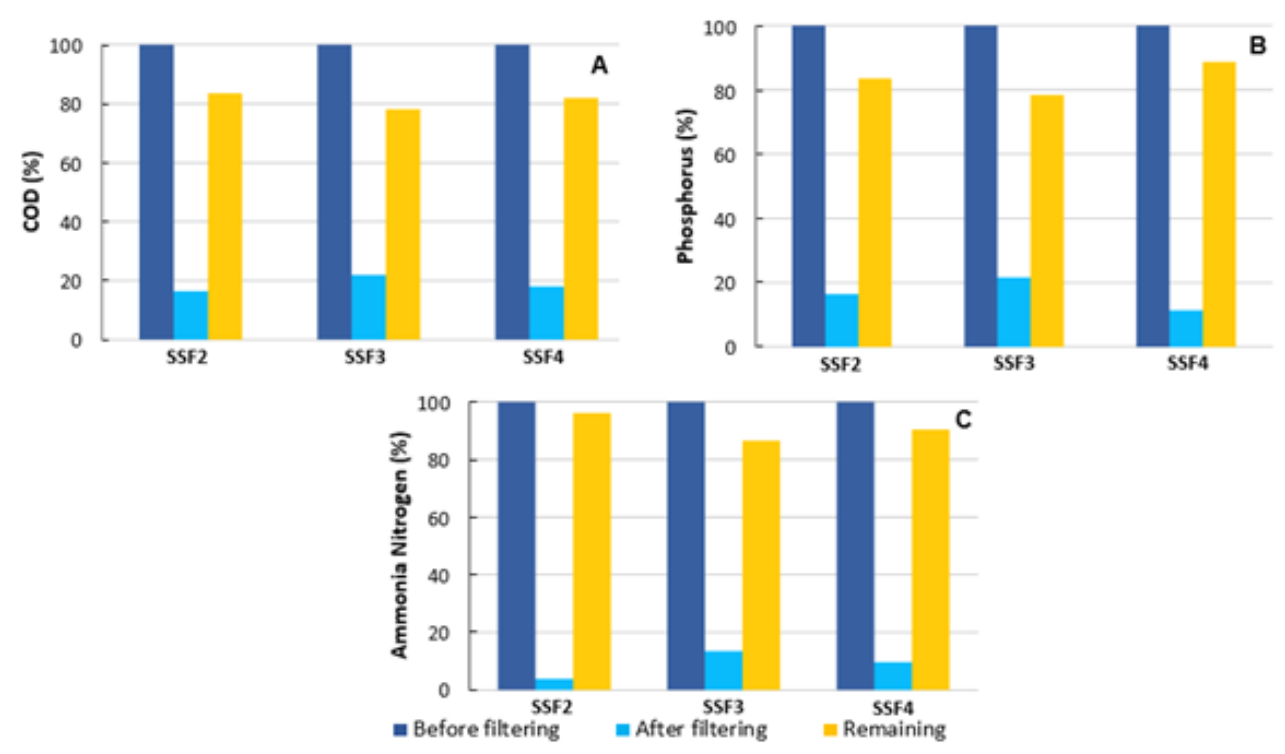

Figure 6. Graphs for the analyses performed at the end of the experiment.

According to the results expressed in Figure 6b, the phosphorus removal by slow sand filters was, on average, $83.54 \%$. Probably, this reduction was due to the microbiological 
assimilation of some bacteria genders, contributing efficiently to reduce the phosphorus concentration in the wastewater. This phosphorus release is vital for agricultural reuse, as this component is essential for storing and transporting energy to the plant. That is, without its presence, no metabolic process occurs (Sousa et al., 2005).

The average ammonia nitrogen removal among filters receiving textile effluent irrigation was $91 \%$ (Figure 6c), approximately. The removal obtained by Brito-Pelegrini (2006) was 12\% for landfill leachate (slurry). The low percentage of removal obtained by this author is explained by the fact that the effluent used in his work consists of landfill percolate, a highly toxic compound with a high recalcitrant organic load.

Table 5 shows the presence of nitrogen in the soil in the form of nitrate $\left(\mathrm{NO}_{3}{ }^{-}\right)$and ammonium $\left(\mathrm{NH}_{4}{ }^{+}\right)$ions in the natural soil sample and each column sample after irrigation with effluent. As expected, for filters irrigated with effluent, ion concentrations increased substantially. In the SSF1 soil, it was noted that the ammonium concentration regarding the raw soil was the same as it was irrigated with distilled water. However, the nitrate ion was leached, because the concentration in the soil was reduced.

In SSF2, SSF3, and SSF4 soils, which were irrigated with effluent, the values of the analyzed ions increased when compared to the raw soil values, with the values of ammonium higher than those of nitrate.

Table 5. Ammonium and nitrate in natural soil and soils after use as a filter.

\begin{tabular}{cccccc}
\hline Parameter & Rough soil & SSF1 & SSF2 & SSF3 & SSF4 \\
\hline Nitrate $\left(\mathrm{mg} \mathrm{kg}^{-1}\right)$ & 16.29 & 9.30 & 56.00 & 70.00 & 81.67 \\
Ammonium $\left(\mathrm{mg} \mathrm{kg}^{-1}\right)$ & 7.10 & 7.00 & 123.67 & 147.00 & 116.67 \\
\hline
\end{tabular}

Although ammonium was converted to nitrate by nitrification, the bacteria responsible for this biological process were unable to perform this conversion clearly. The reduction in microbial biomass may be relevant to nutrients supply such as sodium, indirectly compromising the nutritional disorder (Andrade et al., 2016).

\section{CONCLUSIONS}

The $\mathrm{pH}$ result for samples collected after filtration were within the recommended value range for agricultural reuse water, making the samples that passed the filters more fundamental than the textile effluent used.

Regarding the dissolved oxygen concentration, the filters were able to aerate between the rest period of each slow filter and were able to be used for irrigation.

The average color and turbidity reduction shows that the filters were efficient in removing particulates, dissolved materials, and organic matter, promoting the use of reused water in fertigation practices, performed through drip systems, which did not present clogging problems.

The electrical conductivity values and the salinity concentrations did not reach the allowable range for irrigation, necessitating the use of specific soil types and selected crops if irrigation is made with reused water from the slow sand filters. The high concentration of salts present in the textile effluent can be explained by the fact that the laundry chosen for this research uses salt in its textile production processes to fix color on garments.

Regarding organic matter removal, it was possible to conclude that the slow sand filters presented excellent efficiency concerning the organic matter incorporation in the used soil.

Regarding nutrient concentrations, the filters allowed the incorporation of nutrients in the used soil. Therefore, there was a high removal of these nutrients, evidencing a possible reduction of eutrophication in case of release in any outfall. However, the values obtained for these two nutrients after filtration still classify the reuse waters as suitable for irrigation 
according to international laws.

It is concluded that the simplified effluent post-treatment system of the textile industry, performed by slow sand filters with a $20 \mathrm{~cm}$ thick sand layer, was efficient, presenting no severe problems during its operation.

\section{ACKNOWLEDGMENTS}

This work was carried out with the support of the project "Transfer of Water and Mixtures of Reactive Pollutants in Anthropized Soils" (CNPq process No. 436875/2018-7) and of the Foundation for the Support of Science and Technology of the State of Pernambuco (FACEPE/CAPES process IBPG-0800-3.01/18).

\section{REFERENCES}

ABDEL-FATAH, M. A.; SHERIF, H. O.; AGOUR, F.; HAWASH, S. I. Textile waste water treatment by chemical coagulation technology. Global Journal of Advanced Engineering Technologies and Sciences, v. 2, n. 12, p. 20-28, 2015.

ABNT. NBR 13969: Tanques Sépticos - Unidades de tratamento complementar e disposição final dos efluentes líquidos - Projeto, construção e operação. Rio de Janeiro, 1997. 60 p.

ABNT. NBR 7181: solo - análise granulométrica. Rio de Janeiro, 1984. 13 p.

ABREU, M. C. S.; SILVA FILHO, J. C. L.; OLIVEIRA, B. C.; HOLANDA JÚNIOR, F. L. Perfis estratégicos de conduta social e ambiental: estudos na indústria têxtil nordestina. Gestão da Produção, v. 15, n. 1, p. 159-172, 2008. http://dx.doi.org/10.1590/S0104530X2008000100014

ALEXANDRE, J. I. S.; NETO, S. M. S.; COUTINHO, A. P.; MELO, T. A. T.; GONÇALVES, E. A. P.; GONDIM, M. V. S.; ANTONINO, A. C. D.; RABELO, A. E. C. G. C.; OLIVEIRA, A. L. Sorption of the Direct Black 22 dye in alluvial soil. Revista Ambiente \& Água, v. 15, n. 4, p. 1-13, 2020. http://dx.doi.org/10.4136/ambi-agua.2483

ALVES, A. T. A.; SILVA, L. T. M. S.; ALCÂNTARA, L. R. P.; BARROS, V. H. O.; NETO, S. M. S.; LIMA, V. F.; LIMA, J. R. S.; COUTINHO, A. P. ANTONINO, A. C. D. Sorption of Remazol Black B dye in alluvial soils of the Capibaribe River Basin, Pernambuco, Brazil. Revista Ambiente \& Água, v. 15, n. 2, p. 1-12, 2020. http://dx.doi.org/10.4136/ambi-agua.2491

ANDRADE, L. C.; ANDREAZZA, R.; CAMARGO, F. A. O. Atividade microbiana em solos sob doses de lodo de estação de tratamento de efluentes de um aterro industrial. Ciência Rural, v. 46, n. 2, p. 267-272, 2016. http://dx.doi.org/10.1590/0103-8478cr20140871

APAC. Monitoramento das Chuvas no Estado de Pernambuco. 2019. Available in: http://www.apac.pe.gov.br/meteorologia/chuvas-rmr.php. Access: Sep. 2019.

APHA; AWWA; WEF. Standard Methods for the examination of water and wastewater. 22nd ed. Washington, 2012. 1496 p.

ARMINDO, R. A.; FREITAS, K. S.; SOBENKO, L. R.; LASKOSKI, M.; ARAÚJO, T. F. Qualidade da água, métodos e manejo de irrigação para olericultura. Curitiba: SENAR, 2015. 78 p. 
AUSLAND, G.; STEVIK, T. K.; HANSSEN, J.F.; KOHLER, J.C.; JENSSEN, P.D. Intermittent filtration of wastewater - removal of fecal coliforms. Water Research, v. 36, n. 14, p. 3507-3516, 2002. http://dx.doi.org/10.1016/S0043-1354(02)00060-X

BAÊTA, B. E. L.; LIMA, D. R. S.; SILVA, S. Q.; AQUINO, S. F. Influence of the applied organic load (OLR) on textile wastewater treatment using submerged anaerobic membrane bioreactors (SAMBR) in the presence of redox mediator and powdered activated carbon (PAC). Brazilian Journal of Chemical Engineering, v. 33, n. 4, p. 817 825, 2016. http://dx.doi.org/10.1590/0104-6632.20160334s20150031

BENDIDA, A.; TIDJANI, A. E. B.; BADRI, A.; KENDOUCI, M. A.; NABOU, M. Treatment of domestic wastewater from the town of Bechar by a sand filter (sand of Beni Abbes Bechar Algeria). Energy Procedia, v. 36, p. 825-833, 2013. http://dx.doi.org/10.1016/j.egypro.2013.07.095

BRITO-PELEGRINI, N. N. Sistema de Filtração Lenta no Tratamento de Percolado do Aterro Sanitário de Limeira - SP, 2006, 101f. Dissertação (Mestrado em Engenharia Agrícola; Água e Solo) - Faculdade de Engenharia Agrícola, Universidade Estadual de Campinas, Campinas, 2006.

CHANDANSHIVE, V. V.; RANE, N. R.; TAMBOLI, A. S.; GHOLAVE, A. R.; KHANDARE, R. V.; GOVINDWAR, S. P. Co-plantation of aquatic macrophytes Typha angustifolia and Paspalum scrobiculatum for effective treatment of textile industry effluent. Journal $\begin{array}{lllllll}\text { of Hazardous } & \text { Materials, } & \text { v. 338, } & \text { p. 47-56, }\end{array}$ http://dx.doi.org/10.1016/j.jhazmat.2017.05.021

CHICATTO, J. A.; RAINERT, K. T.; GONÇALVES, M. J.; HELM, C. V.; ALTMAJER-VAZ, D.; TAVARES, L. B. B. Decolorization of textile industry wastewater in solid state fermentation with Peach-Palm (Bactris gasipaes) residue. Brazilian Journal of Biology, v. 78, n. 4, p. 718-727, 2018. http://dx.doi.org/10.1590/1519-6984.175074

CLAESSEN, M. E. C. Manual de métodos de análise de solo. Rio de Janeiro: EMBRAPACNPS, 1997. $212 \mathrm{p}$.

COELHO, E. R. C.; DI BERNARDO, L. Remoção de atrazina e metabólitos pela filtração lenta com leito de areia e carvão ativado granular. Engenharia Sanitária e Ambiental, v. 17, n. 3, p. 269-276, 2012. http://dx.doi.org/10.1590/S1413-41522012000300003

CONAMA (Brasil). Resolução n ${ }^{\circ} 430$ de 13 de maio 2011. Dispõe sobre as condições e padrões de lançamento de efluentes, complementa e altera a Resolução no 357, de 17 de março de 2005, do Conselho Nacional do Meio Ambiente-CONAMA. Diário Oficial [da] União: seção 1, Brasília, DF, n. 92, p. 89, 16 maio 2011.

CORDEIRO, G. G. Qualidade de Água para Fins de Irrigação: conceitos básicos e práticos. Petrolina: Embrapa Semiárido, 2001. 31 p.

DIAS, I. N. MBBR acoplado a filtro lento de areia e a osmose inversa para tratamento de efluente da indústria de petróleo visando reuso. 2011. 153f. Dissertação (Mestrado em Engenharia Química) - Instituto Alberto Luiz Coimbra, Rio de Janeiro, 2011.

EGEA-CORBACHO, A.; GUTIÉRREZ, S.; QUIROGA, J. M Removal of emerging contaminants from wastewater through pilot plants using intermitente sand/coke filters for its subsequent reuse. Science of the Total Environment, v. 646, p. 1232-1240, 2019. http://dx.doi.org/10.1016/j.scitotenv.2018.07.399 
ESTEVES, F. A.; MEIRELLES-PEREIRA, F. Fundamentos de limnología. Rio de Janeiro: Interciência, 2011. 826 p.

GRACE, M. A.; HEALY, M. G.; CLIFFORD, E. Performance and surface clogging in intermittently loaded and slow sand filters containing novel media. Journal of

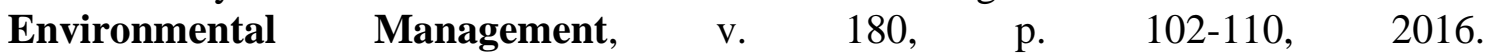
http://dx.doi.org/10.1016/j.jenvman.2016.05.018

HELLER, L.; VIEIRA, M. B.C. M.; BRITO, L. L. A.; SALVADOR, D. P. Association between the concentration of protozoa and surrogates in effluents of the slow sand filtration for water treatment. Brazilian Journal of Microbiology, v. 38, n. 2, p. 337-345, 2007. http://dx.doi.org/10.1590/S1517-83822007000200029

IBGE. Brasil/Pernambuco/Caruaru. IBGE, 2010. Available in: https://cidades.ibge.gov.br/brasil/pe/caruaru/pesquisa/23/25207?tipo=ranking\&ano=201 0\&indicador=25207. Access: April 2018.

JEONG, H.; KIM, H.; JANG, T. Irrigation water quality standards for indirect wastewater reuse in agriculture: a contribution toward sustainable wastewater reuse in South Korea. Water, v. 8, n. 4, p. 1-18, 2016. http://dx.doi.org/10.3390/w8040169

JIMENO, V. A. V.; MERCADO, E. R. A.; BALLESTEROS, D. M. P.; YÉPEZ, J. G. T.; VEJA, M. E. P. Uso de la microalga Chlorella sp. Viva em suspensión em la decoloración del agua residual de uma empresa textil. Prospect, v. 15, n. 1, p. 93-99, 2017. http://dx.doi.org/10.15665/rp.v15i1.829

MANCUSO, P. C. S.; SANTOS, H. F. Reuso de água. São Paulo: Manole, 2003. 590 p.

PATERnIANI, J. E. S.; SILVA, M. J. M.; RIBEIRO, T. A. P.; AIROLDI, R. P. S. A importância da qualidade da água nos projetos de irrigação - um estudo de caso. Revista Brasileira de Engenharia de Biossistemas, v. 2, n. 3, p. 223-230, 2008. http://dx.doi.org/10.18011/bioeng 2008v2n3 p 223-230

PATERNIANI, J. E. S.; SILVA, M. J. M.; RIBEIRO, T. A. P.; BARBOSA, M. Pré-filtração em pedregulho e filtração lenta com areia, manta não tecida e carvão ativado para polimento de efluentes domésticos tratados em leitos cultivados. Engenharia Agrícola, v. 31, n. 4, p. 803-812, 2011. http://dx.doi.org/10.1590/S0100-69162011000400018

ROCHA, R.; SOARES, R. R. Water scarcity and birth outcomes in the Brazilian semiarid.

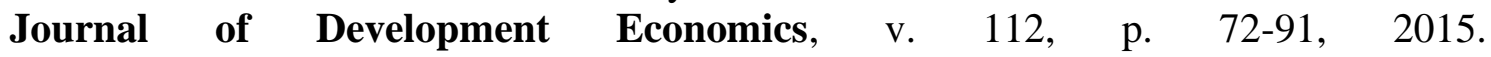
http://dx.doi.org/10.1016/j.jdeveco.2014.10.003

SANTOS, E. M. A.; NASCIMENTO, A. T. P.; PAUlinO, T. R. S.; BARROSO, B. C. S.; AGUIAR, C. R. Reator anaeróbio tipo UASB conjugado com processo Fenton para remoção de cor e demanda química de oxigênio de água residuária sintética de indústria têxtil. Engenharia Sanitária e Ambiental, v. 22, n. 2, p. 285-292, 2017. http://dx.doi.org/10.1590/S1413-41522016148154

SOUSA, J. T.; VAN HAANDEL, A. C.; CAVALCANTI, P. F. F.; FIGUEIREDO, A. M. F.. Tratamento de esgoto para uso na agricultura do semi-árido nordestino. Engenharia Sanitária e Ambiental, v. 10, n. 3, p. 260-265, 2005. http://dx.doi.org/10.1590/S141341522005000300011 
SOUZA, L. H.; NOVAIS, R. F.; ALVAREZ, V. H.; VILLANI, E. M. A. Efeito do pH do solo rizosférico e não rizosférico de plantas de soja inoculadas com Bradyrhizobium japonicum na absorção de boro, cobre, ferro, manganês e zinco. Revista Brasileira de Ciência do Solo, v. 34, n. 5, p. 1641-1652, 2010. http://dx.doi.org/10.1590/S010006832010000500017

TONETTI, A. L.; FILHO, B. C.; NICOLAU, C. E.; BARBOSA, M.; TONON, D. Tratamento de esgoto e produção de água de reuso com o emprego de filtros de areia. Engenharia Sanitária e Ambiental, v. 17, n. 3, p. 287-294, 2012. http://dx.doi.org/10.1590/S141341522012000300005

USEPA. Wastewater Technology Fact Sheet Intermittent Sand Filters. Washington, D.C., 1999. Available in: https://www3.epa.gov/npdes/pubs/isf.pdf. Access: Aug. 2019.

VERMA, A. K.; DASH, R. R.; BHUNIA, P. A review on chemical coagulation/flocculation technologies for removal of colour from textile wastewaters. Journal of Environmental $\begin{array}{lllllll}\text { Management, } & \text { v. } & 93, & \text { n. } & 1, & \text { p. } & 154-168,\end{array}$ http://dx.doi.org/10.1016/j.jenvman.2011.09.012 